\title{
研究室紹介 \\ 北陸先端科学技術大学院大学 マテリアルサイエンス系 物質化学領域 山口政之研究室
}

\author{
山口 政之*，木田 拓充 \\ (原稿受理： 2021 年 7 月 2 日)
}

石川県能美市に位置する北陸先端科学技術大学院大学 (JAIST) は, 学部を置くことなく, 独自のキャンパスと教 育研究組織を持つ日本で最初の国立大学院大学として平成 2 年 10 月に創設された。昨年, 創立 30 周年を迎えたところで あり, 記念行事としてノーベル賞を受賞された吉野彰先生に ご講演頂いた

本学には学部生がいないため, 入学生はほぼ全員が初対面 となる。国公立大学, 私立大学, 高専の専攻科はもとより, 企業在籍者や勤務先を辞めて入学した人など，学生のバック グラウンドはさまざまであり，日本全国のみならず世界中か ら学生が集まっている. 特に, 留学生比率は $50 \%$ 程度とか なり高い. 学部がないために学生募集は常に最優先事項と なっており教員は辛い思いをするのであるが, 一方, 学生に とってはかなり恵まれた環境が整っている，就職活動への手 厚い支援体制や充実した奨学金制度はもちろんのことだが,

例えば, 海外で開催される国際学会へ参加する場合, 旅費な どの経済的サポートがあるばかりでなく，ネイティブによる 英語の指導を受けることもできる，多くの卒業生がこの制度 を利用して国際学会で発表してきたが, どういうわけか当研 究室の学生は有名な観光地ばかり訪問しているような気が する.

本学では，2016年にそれまで3つあった研究科をひとつ に統合した。一研究科体制後は, マテリアルサイエンス系, 情報科学系, 知識科学系がそれぞれ異なる学位を授与するも のの, 異分野統合を目指した教育・研究活動が進められてい る. また, 学位による分類 (学系) とは別に, 9つの研究領 域が存在している。すなわち, 教員, 学生ともに, ひとつの 学系とひとつの研究領域に所属することになる。この研究領 域も来年度からは10の領域に再編されることになっている11.

我々は, 学系としてはマテリアルサイエンス系, 研究領域 としては物質化学領域に所属している。ちなみに来年度から は領域再編に伴って,「物質化学フロンティア研究領域」に 所属することになる（領域再編という言葉が悲しくなるほど のマイナーな名称変更である) , 現在の物質化学領域には高 分子を対象とする研究室が多く, 研究室間の垣根を超えた研 究活動が比較的活発に行なわれている。なお, マテリアルサ イエンス系には山口が二名在籍しているため, 我々の研究室 は山口政之研究室と呼ばれている。2005 年に山口が着任し

* ₹923-1292 石川県能美市旭台1-1

E-mail : m_yama@jaist.ac.jp, Tel : 0761-51-1621
て研究室活動を始め, 2021 年 10 月までに 78 人が修士課程, 24 人が博士後期課程を修了している。また，今年の 4 月に は木田が助教として着任した。 2021 年 12 月現在のメンバー は, 教員 2 名, 秘書 1 名, 博士後期課程学生 6 名, 修士課程 学生 7 名となっている（Fig. 1). 学生 13 名のうち 7 名が留 学生（タイ、ベトナム, 中国が各 2 名, マレーシア 1 名), 3 名が社会人学生となっている。 バックグラウンドがあまりに 異なるためか, それなりにチームワークは良さそうに思う。 ちなみにこれまでは夕イからの留学生が多く, 学生として 10 人以上, インターンシップを含めると 35 人以上が当研究 室に在籍している。数年前にはバンコクで同空会も行った (Fig. 2).

民間企業に 16 年間勤務していた山口は高分子成形加工の 業務に関わってきた経験があることから, 回転型のレオメー タ以外に種々のレオメータを設置している，例えば，毛管粘

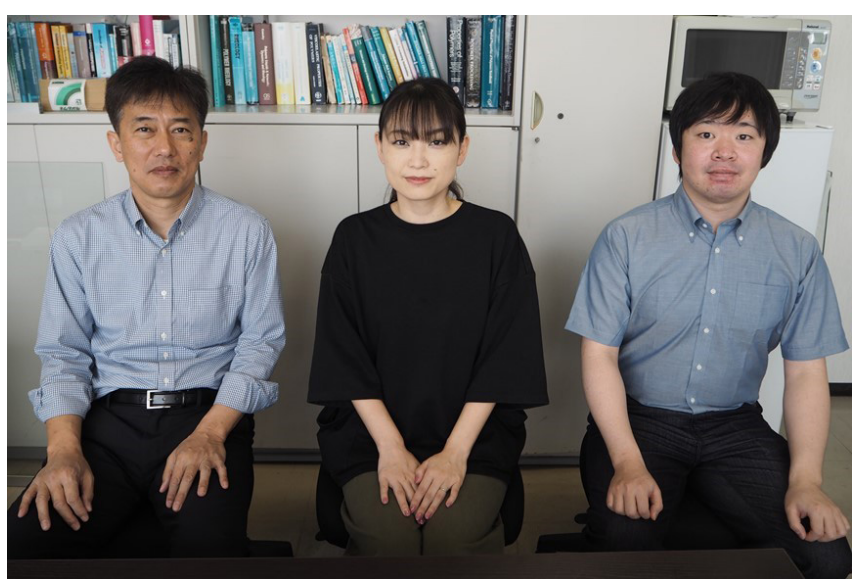

Fig. 1 現在の研究室スタッフ（中央は秘書の松本さん）

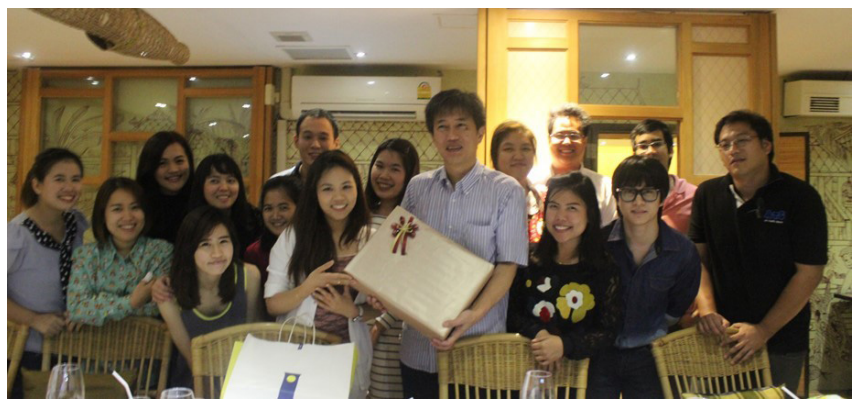

Fig. 2 バンコクでの同空会の様子. 
度計には，さまざまなダイを取り揃えて Bagley 補正や Mooney 法によるスリップ性の評価を可能にしている他, 溶 融張力や溶融延伸性, スウェル比の測定を行っている.さら には, 矩形ダイと自作の超小型チルロールを用いて, ごく少 量 $(10 \mathrm{~g}$ 程度) のサンプルでもフィルム成形を可能にしてい る. また, 最近, ツインキャピラリーレオメータを新たに設 置し, これに特殊なダイを備えることにより芯鞘構造の繊維 を試作している (Fig. 3). こちらも必要なサンプル量はごく わずかである. その他, 加熱せん断ステージに, 偏光顕微鏡 とフォトディテクターを組み合わせて, 流動場での構造形成 や, 複合材料の分子配向を読み取る装置を立ち上げた (Fig. 4).この装置を用いて, 流動場での結晶化, 流動誘起 相変化や誘導誘起偏析現象, 高分子中に打码低分子化合物 の配向状態などについて研究を進めているところである。レ オ・オプティクスに関しては, 固体材料を対象にした装置も いくつか所有しているが, こちらの装置の立ち上げには, 大 阪大学 井上正志教授, 名古屋工業大学 信川省吾准教授のご 支援をいただいた（Fig. 5)。なお，信川准教授には2011年 4 月から 2015 年 9 月まで当研究室に在籍してもらい, 研究 活動全般にご尽力いただいた。その他，小型フィルム成形機， 小型加熱二軸延伸機, 内容量が異なる種々の混練機 $(5 \mathrm{cc}-60 \mathrm{cc})$ など, 本格的ではないものの工業的な「匂 い」のする装置を揃えている.

山口は企業在籍時から現在に至るまで, 市販されているプ ラスチックやゴムの溶融レオロジー特性や成形加工性を改良 する手法, 成形加工による構造制御を利用した材料設計など に興味を持って研究開発を行ってきた ${ }^{2-9}$. 特に, 伸長流動場 におけるレオロジー特性の制御, 結晶核剤を利用した分子配 向の制御, ナノ粒子の分散制御, 位相差フィルムの設計など に関心を持ち, 研究対象としてきた。大学に転籍後は, Polymer Processing Society や Society of Plastic Engineers な゙ が主催し毎年開催されている国際会議にできる限り出席し研 究成果を発表している。後者の学会ではApplied Rheology Divisionの Board member となっており, 日本からの発表を 勧誘している ${ }^{10)}$ (勧誘はしているがこれまで一度も成功して いない). 今後も現象論的なレオロジー研究に軸足を置き, いわゆる工業レオロジーの分野を中心に貢献したいと考えて いる. また, 木田はこれまで金沢大学 新田研究室, 広島大 学 塩野研究室, 名古屋大学 増㴊研究室で, 主としてポリオ レフィンを中心とした固体物性について研究を行ってきた. 最近は分子量や分子量分布と固体物性との関係や, 分光測定 を用いた構造解析を主な研究テーマとしている. 今後, 当研 究室が所有するさまざまな装置や知見を活用して研究対象を さらに広げ, 研究を推進していきたいと考えている。

\section{ACKNOWLEDGEMENTS}

これまでお世話になった多くの方々に感謝しますとともに， 今後ともご支援のほどよろしくお願いいたします。当地は交 通が不便なところに立地していますが，近くに温泉があり， 造り酒屋があり, 美味しい日本海の看に囲まれて住み心地の 良いところです．金沢観光のついでに当研究室にもどうぞお 立ち寄りください.

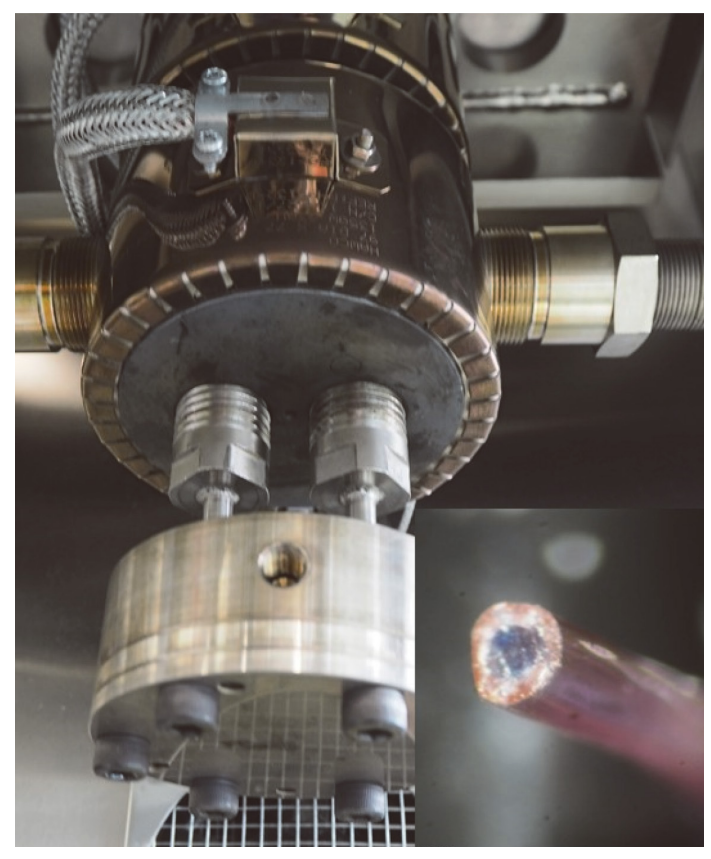

Fig.3 芯鞘瀻維用のダイを設置したツインキャピラリー レオメータ (右下は得られた繊維)。

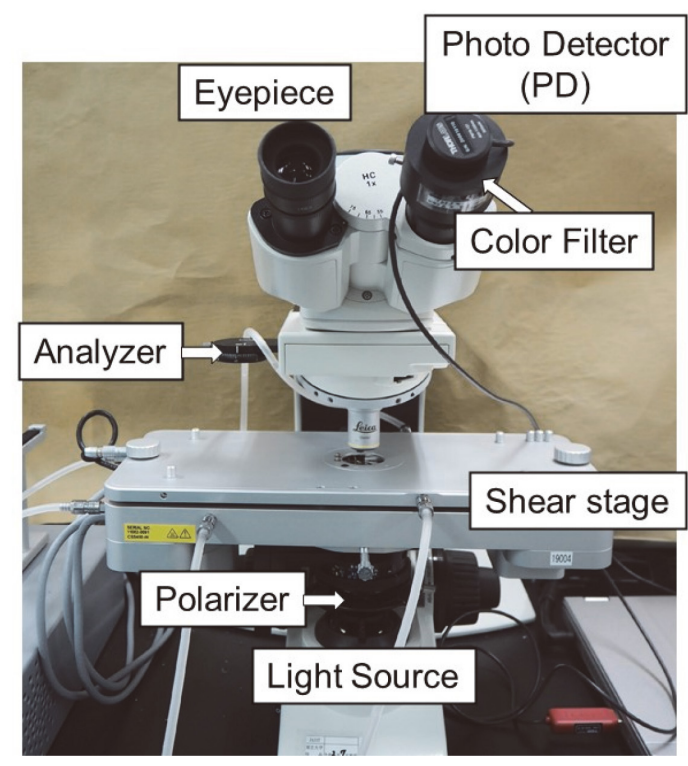

Fig. 4 加熱せん断ステージ, 偏光顕微鏡, フォトディ テクターを組み合わせた装置。

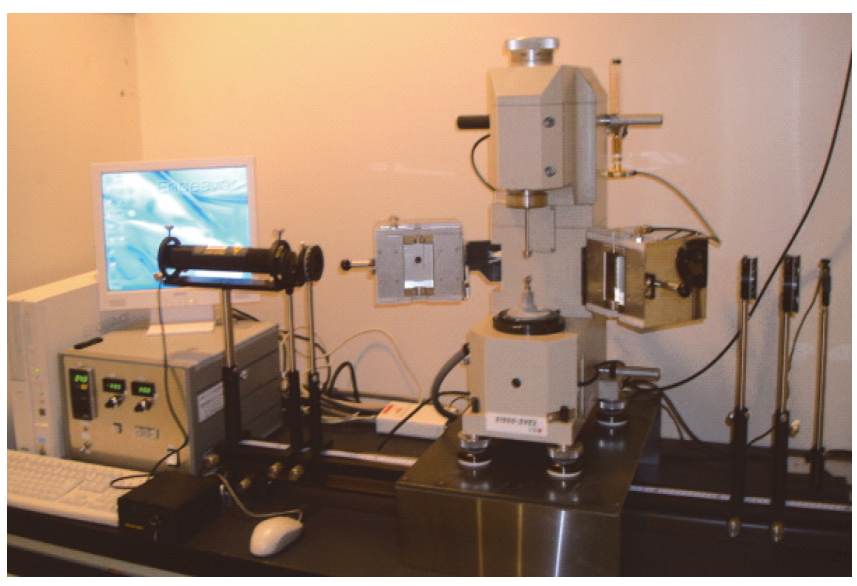

Fig. 5 固体フィルムを対象にした一軸延伸 - 複屈折同時測定装置. 


\section{REFERENCES}

1) www.jaist.ac.jp/areas/data/laboratoryguide-10areas.pdf

2) Yamaguchi M, Fujii Y, Phulkerd P, Nihon Reoroji Gakkaishi (J Soc Rheol Jpn), 48, 109 (2020).

3) Nishikawa R, Yoon H, Yamaguchi M, Nihon Reoroji Gakkaishi (J Soc Rheol Jpn), 47, 105 (2019).

4) Fujii Y, Nishikawa R, Phulkerd P, Yamaguchi M, J Rheol, 63, 11 (2019).

5) Seemork J, Sako T, Mohd Amran BMA, Yamaguchi M, J Rheol, 61, 1 (2017).
6) Shimada H, Kiyama A, Phulkerd P, Yamaguchi M, Nihon Reoroji Gakkaishi (J Soc Rheol Jpn), 45, 19 (2017).

7) Seemork J, Itoh T, Nobukawa S, Yamaguchi M, Nihon Reoroji Gakkaishi (J Soc Rheol Jpn), 44, 23 (2016).

8) Siriprumpoonthum M, Nobukawa S, Satoh Y, Sasaki H, Yamaguchi M, J. Rheol, 58, 449 (2014).

9) Yokohara T, Nobukawa S, Yamaguchi M, J. Rheol, 55, 1205 (2011).

10) https://www.4spe.org/i4a/pages/index.cfm?pageID $=3544$ 